\title{
LOCUS OF CONTROL DAN PROKRASTINASI PADA MAHASISWA PENDIDIKAN EKONOMI ANGKATAN 2013 FAKULTAS EKONOMI UNIVERSITAS NEGERI JAKARTA
}

\author{
Yosefhin Rika Ernima \\ Fakultas Ekonomi, Universitas Negeri Jakarta \\ yosefin@feunj.ac.id \\ Widya Parimita \\ Fakultas Ekonomi, Universitas Negeri Jakarta \\ widya_parimita@unj.ac.id \\ Agus Wibowo \\ Fakultas Ekonomi, Universitas Negeri Jakarta \\ agus-wibowo@unj.ac.id
}

\begin{abstract}
ABSTRACK
This study aims to determine wheather there is any effect on the Economics of Education student procrastination force in 2013 Faculty of Economics, Universitas Negeri Jakarta. This research was carried out for 2 months starting from the month of May 2016 to June 2016. The research method used is survey method with the correlational approach. The population in this study were students of Economic Education in 2013 totaling 210 students. According to the table and sample population with 5\% level of misunderstanding the obtained sample of 210 students. $X$ variable data about the locus of control is the primary data in the form of questionnaire and $Y$ about procrastination is the primary data in the form of a questionnaire. Test requirements analysis done is to find the regression equation obtained was $\hat{Y}=139,57+0,74 X$. Normality test results Liliefors produce $L_{\text {hitung }}=0,0764$ dan $L_{\text {tabel }}=0,0786$ at the significance level (a) $=0: 05$ to the number of samples $(n)$ 127. Because $L_{\text {hitung }}=(0,0764)<L_{\text {tabel }}=$ $(0,0786)$ then the variable $X$ and $Y$ have normal distribution. Testing the hypothesis with a significance test of regression produces $F_{\text {hitung }}(86,89)>F_{\text {tabel }}$ $(3,939)$, which means a significant regression equation. produce regression linearity test of $F_{\text {hitung }}(0,19)<F_{\text {tabel }}(1,59)$ so $F_{\text {hitung }}<F_{\text {tabel }}$ it can be concluded that the model is a linear regression equation. Product moment correlation coefficient generating $r_{\text {hitung }}=-0.6403$. T-test produces thitung $(-9,321)>t_{\text {tabel }}$ (1.979). Thus it can be stated correlation coefficient $r_{x y}=-0.6403$ is significant. The coefficient of determination obtained at $41,01 \%$ indicates that $41,01 \%$ variable procrastination is determined by the locus of control and the remaining $58,99 \%$ influenced by other variables not examined. Based on the results of this study concluded that there are significant negative and significant correlation
\end{abstract}


between locus of control with procrastination on Economic Education class of 2013 student Faculty of Economics, Universitas Negeri Jakarta.

Keywords: locus of control, procrastination

\section{ABSTRAK}

Penelitian ini bertujuan untuk mengetahui apakah terdapat pengaruh pada daya putus asa mahasiswa Pendidikan Ekonomi angkatan 2013 Fakultas Ekonomi, Universitas Negeri Jakarta. Penelitian ini dilakukan selama 2 bulan mulai bulan Mei 2016 sampai Juni 2016. Metode penelitian yang digunakan adalah metode survei dengan pendekatan korelasional. Populasi dalam penelitian ini adalah mahasiswa Pendidikan Ekonomi angkatan 2013 sebanyak 210 siswa. Menurut table dan sampel populasi dengan tingkat kesalahan 5\% diperoleh sampel 210 siswa. Data variabel $\mathrm{X}$ tentang lokus kontrol adalah data primer berupa kuesioner dan $\mathrm{Y}$ tentang penundaan adalah data primer berupa kuesioner. Ujian analisis kebutuhan yang dilakukan adalah untuk mengetahui persamaan regresi yang diperoleh yaitu $\hat{Y}=139.57+0.74 X$. Hasil uji normalitas Liliefors menghasilkan L-hitung $=0,0764$ dan L-tabel $=0,0786$ pada tingkat signifikansi $(\alpha)=0.05$ dengan jumlah sampel $(n) 127$. KarenaL $L_{\text {hitung }}=(0.0764)<L_{\text {tabe }}=$ (0.0786) maka variabel $X$ dan $Y$ memiliki distribusi normal. Pengujian hipotesis dengan uji signifikan regresi menghasilkan $F_{\text {hitung }}(86.89)>F_{\text {tabel }}$ (3.939), yang berarti persaman regresi yang signifikan. Hasil uji lineritas regresi $F_{\text {hitung }}(0,19)$ $<\mathrm{F}_{\text {tabel }}(1.59)$ sehingga $\mathrm{F}_{\text {hitung }}<\mathrm{F}_{\text {tabel }}$ dapat disimpulkan bahwa model adalah persamaan regresi linier. Koefisien korelasi product moment menghasilkan $\mathrm{r}$ hitung $=-0,6403$. $T_{\text {-test }}$ menghasilkan $t_{\text {-hitung }}(-9,321)>$ table (1.979). Dengan demikian dapat dikatakan koefisien korelasi $r_{x y}=-0,6403$ signifikan. Koefisien determinasi yang diperoleh sebesar $41.01 \%$ mengindikasikan bahwa variabel dependen $41,01 \%$ ditentukan oleh lokus kontrol dan sisanya $58.99 \%$ dipengaruhi oleh variabel lain yang tidak diperiksa. Berdasarkan hasil penelitian ini disimpulkan bahwa terdapat hubungan negatif dan signifikan antara lokus kontrol dengan penundaan pada mahasiswa Prodi Pendidikan Ekonomi angkatan 2013 Fakultas Ekonomi Universitas Negeri Jakarta.

Kata kunci: Lokus kontrol, penundan

\section{PENDAHULUAN}

Kehidupan mahasiswa di perguruan tinggi tidak terlepas dari Tri Darma Perguruan Tinggi, yaitu mendapatkan pendidikan, melakukan penelitian, dan pengabdian pada masyarakat. Kedewasaaan dalam melaksanakan kegiatan belajarnya dapat tercapai apabila mahasiswa mengerahkan kemampuan dan kesempatan yang ada pada dirinya. Mahasiswa perlu mengusahakan dan mengembangkan kemampuan dan kesempatan bagi dirinya. Dalam upaya ini diperlukan bimbingan dari dosen agar dapat menjadi mahasiswa yang mandiri dalam 
kegiatan belajarnya sehingga seorang mahasiswa dapat berhasil menyelesaikan studinya.

Mahasiswa dalam kaitannya dengan dunia pendidikan, merupkan salah satu substansi yang perlu diperhatikan, karena mahasiswa merupakan penerjemah terhadap dinamika ilmu pengetahuan tersebut. Mahasiswa secara umum merupakan sunjek yang memiliki potensi untuk mengembangkan pola kehidupannya, dan sekaligus menjadi objek dalam keseluruhan bentuk aktivitas dan kreativitasnya, sehingga diharapkan mampu menunjukkan kualitas daya yang dimilikinya.

Sebagai mahasiswa dalam usia muda, tentunya mereka tidak luput dari permasalahan yang berkaitan dengan kegiatan belajar. Pada umumnya, dalam usia ini mereka cenderung lebih suka melakukan aktivitas yang dianggapnya lebih menyenangkan seperti menonton film, jalan dengan teman dan chatting di media sosial, daripada melakukan tugasnya sebagai seorang siswa. Selain itu, mereka juga kerap kali merasa tidak nyaman dengan kondisi sekolah, lingkungan teman sebaya, cara guru mengajar dan tugas-tugas sekolah yang dianggap terlalu banyak. Kondisi seperti ini, tak jarang menyebabkan para siswa untuk menunda belajar dan menyelesaikan tugas-tugas sekolahnya dengan melakukan kegiatan lain yang dianggapnya lebih menyenangkan. Hal ini mereka lakukan sebagai bentuk pemberontakan terhadap kondisi yang mereka hadapi.
Dalam istilah psikologi, perilaku menunda pekerjaan untuk melakukan berbagai kegiatan yang tidak bermanfaat ini dikenal dengan istilah Prokrastinasi. Perilaku ini berkorelasi dengan rendahnya harga diri (self esteem), depresi, pikiran-pikiran atau gagasan irasional, kecemasan, dan kurang percaya pada kemampuan diri. Menurut penelitian yang dilakukan pada pelaku Prokrastinasi, mereka cenderung menjadi seorang pembohong karena merekaakan berusaha mencari-cari cara dan alasan untuk menghindari tugas yang tidak disukainya. Biasanya perilaku prokrastinasi meyakini bahwa tugas yang mereka lakukan sulit untuk diselesaikan. Terkadang hanya dengan memikirkan hal itu saja akan membuat mereka tidak nyaman, cemas, dan ketakutan. Melakukan penundaan merupakan cara untuk mematikan perasaan tersebut, juga penundaan dijadikan sebagai suatu jenis perlindungan diri untuk mengatasi suatu permasalahan.

Berdasarkan pengalaman sebelumnya banyak mahasiswa yang mengerjakan atau menyelesaikan pekerjaan rumahnya di kampus atau adapula tugas yang diberikan oleh dosen yang berhalangan hadir untuk diselesaikan pada hari itu, namun mereka tidak selesaikan atau bahkan tidak dikerjakan sama sekali. Kebanyakan dari mereka lebih suka berbicara dengan teman, mendengarkan lagu, bermalasmalasan, bermain sosial media atau chatting dan bahkan berfoto-foto dengan gadget yang dimilikinya. 
Mahasiswa yang melakukan tindakan prokrastinasi umumnya tidak dapat mengelola waktu belajarnya dengan baik. Mereka tidak memulai ataupun menyelesaikan tugasnya dengan segera dan beranggapan bahwa masih memiliki cukup waktu untuk menyelesaikan tugas-tugas tersebut. Sehingga tugas yang harus diselesaikan semakin menumpuk dan mereka kesulitan untuk memilih tugas yang hendak diselesaikan terlebih dahulu. Padaakhirnya, mereka akan mengerjakannya dalam tengat waktu (deadline), sehingga hasil yang didapatkan tidak optimal.

Selain itu, kondisi fisik ataupun mental yang lelah juga menjadi penyebab siswa melakukan tindakan prokrastinasi. Kelelahan (fatigue) merupakan keadaan dimana tubuh dan jiwa terasa letih bukan hanya sekedar capek, tetapi lesu dan tidak bergairah, menggambarkan keadaan fisik dan/atau mental menjadi lelah dan lemah. Pada kondisi ini, kemampuan fisik ataupun mental mahasiswa menurun yang diikuti perasaan mengantuk dan tidak mampu berkonsentrasi dengan baik, sehingga berdampak pada tertundanya pengerjaan ataupun penyelesaian tugas-tugas. Kelelahan dan prokrastinasi memiliki keterkaitan, keduanya saling bergandengan tangan. Tidak hanya sebagai hasil, namun prokrastinasi juga dapat mengakibatkan mahasiswa merasa kelelahan.

Ketika mahasiswa merasa lelah, mereka akan melakukan penundaan terhadap tugastugasnya dan memilih untuk menyelesaikannya dikemudian hari. Kondisi demikian mengakibatkan tugas-tugas tersebut semakin menumpuk dan mengubah persepsi terhadap tugas sederhana menjadi sulit untuk diselesaikan. Pada akhirnya mereka akan terus melakukan penundaan sebagai bentuk penghindaran terhadap tugas-tugas tersebut dan membuat mereka menjadi kewalahan dan kelelahan dalam menyelesaikannya. Mahasiswa dengan motivasi untuk berhasil atau berprestasi yang rendah juga cenderung akan melakukan tindakan prokrastinasi terhadap kewajiban atau tugastugas sekolahnya. Motivasi berprestasi merupakan suatu dorongan dalam diri seseorang untuk mencapai tujuan sukses dan berhasildalam suatu kompetisi yang diukur dengan beberapa ukuran keberhasilan, misalnya dengan membandingkan prestasi sebelumnya dengan prestasi saat ini atau membandingkan prestasi sendiri dengan orang lain. Mahasiswa dengan motivasi berprestasi yang rendah cenderung lebih suka melakukan kegiatan yang tidak ada kaitannya dengan keberhasilan studi mereka dan menyia-nyiakan waktunya untuk melakukan kegiatan yang dianggapnya lebih menyenangkan daripada memulai untuk belajar ataupun menyelesaikan tugastugasnya.

Pada umumnya, siswa yang melakukan tindakan prokrastinasi, memilik harga diri (self-esteem) yang rendah. Self-esteem 
menggambarkan sejauh mana individu tersebut menilai dirinya sebagai orang yang memiliki kemampuan dan keberartian. Harga diri (self-esteem) yang rendah akan menolak dirinya sebagai sesuatu yang berharga dan tidak bertanggungjawab terhadap kehidupannya. Pentingnya pemenuhan harga diri individu, khususnya pada kalangan remaja, terkait erat dengan dampak negatif jika mereka tidak memiliki harga diri yang mantap. Mereka akan mengalami kesulitan dalam menampilkan perilaku sosialnya, merasa inferior dan canggung. Namun apabila kebutuhan harga diri mereka dapat terpenuhi secara memadai, kemungkinan mereka akan memperoleh kesuksesan, percaya diri (Self-confidence), bertanggungjawab dan merasa memiliki nilai dalam kehidupannya. Artinya, jika seorang siswa memiliki harga diri (self-esteem) yang baik, mereka akan lebih percaya diri dan bertanggung jawab dalam kehidupannya termasuk untuk urusan akademisnya. Sehingga, kemungkinandari mereka untuk melakukan tindakan prokrastinasi sangat kecil.

Selanjutnya, faktor yang menjadi penyebab tindakan prokrastinasi yakni perasaan takut gagal (fear of failure), yang merupakan suatu dorongan untuk menghindari kegagalan terutama konsekuensi negatif kegagalan berupa rasa malu. Rasa takut sangatlah wajar dialami oleh setiap orang, terlebih lagi pada mahasiswa di usia remaja. Banyak hal yang membuat mereka merasa takut gagal, misalnya dalam menyelesaikan tugas akademik dan saat menghadapi ujian. Mahasiswa yang merasa takut gagal umumnya tidak percaya terhadap kemampuan yang dimilikinya, sehingga cenderung merasa bahwa tugas yang diberikan atau ujian yang akan dihadapi dirasa sangat sulit baginya. Dalam kondisi ini, beberapa siswa berusaha untuk melawannya dengan belajar lebih giat ataupun mengikuti diskusi kelompok di luar kelas. Namun, beberapa lainnya memilih untuk melakukan penghindaran terhadap tugas dan ujian tersebut dengan melakukan aktivitas yang lebih menyenangkan untuk menutupi rasa cemas dan ketakutan yang dihadapinya.

$\mathrm{Hal}$ lainnya yang menyebabkan siswa melakukan tindakan prokrastinasi yakni tingkat Locus of Control (LOC) yang dimiliki oleh mahasiswa. Locus of control atau diartikan sebagai persepsi seseorang tentang penyebab kesuksesan atau kegagalan dalam melaksanakan pekerjaannya. Seseorang memiliki kecenderungan internal locus of control memandang bahw segala sesuatu yang dialaminya, baik yang kurang berbentuk peristiwa, kejadian, nasib atau takdir disebabkan karena kendali dirinya sendiri. Seseorang mampu mengendalikan situasi dan kondisi yang terjadi pada dirinya sendiri. Berbeda dengan orang yang cenderung eksternallocus of control, seseorang beranggapan bahwa segala peristiwa, kejadian,takdir dan nasib disebabkan karena kendali dari faktor eksternal, tidak mempu mengendalikan situasi dan kondisi 
yang terjadi di lingkungan sekitarnya.

Selain itu, rasa takut akan kegagalan (fear failure) juga disebabkan karena target pencapaian yang ditentukan terlampau tinggi.Penundaan dikategorikan sebagai prokrastinasi apabila dilakukan secara sengaja dan berulang-ulang, dengan melakukan aktivitas lain yang tidak diperlukan dalam pengerjaan tugas. Penundaan yang telah menjadi respon tetap atau kebiasaan dipandang sebagai trait prokrastinasi. Prokrastinasi mungkin dapat menjerat siapapun dan dalam jabatan apapun, termasuk mahasiswa Pendidikan Ekonomi Fakultas Ekonomi UNJ angkatan 2013. Terlebih lagi di era globalisasi saat ini yang memperlihatkan kecanggihan teknologi. Teknologi caggih serta beragam media sosial tak dapat dipungkiri juga menjadi salah satu alasan maraknya tindakan prokrastinasi saat ini. Kecanduan bermain gadget, chatting di media sosial membuat sebagian mahasiswa merasa nyaman dan menunda setiap tugas akademiknya untuk menghilangkan kepenatan dalam dirinya. Prokrastinasi yang dilakukan secara berulangkali akan menyebabkan mahasiswa terjerat dalam lingkaran prokrtasinasi, dan tidak menutup kemungkinan akan menghambat pencapaian prestasi mereka dan kesuksesan belajarnya.

\section{KAJIAN TEORITIK Prokrastinasi}

Kata prokrastinasi sudah ada sejak abad ke-16 yang berasal dari kata procrastinare. Pro berarti maju dan crastinus berarti menjadi hari esok. Jadi, bila digabungkan keduanya menjadi prokrastinasi yang berarti menangguhkan atau menunda sampai hari esok (Michael Tefula(Tefula, 2014).Namun, definisi tersebut terlalu umum dan sulit dibedakan dengan penundaan pada umumnya. Seperti yang dikatakan oleh Timothy seorang ahli psikologi dalam Tefula bukunya yang berjudul procrastinator'sDigest bahwa, "all procrastination is delay, but not all delay is procrastination." Artinya, semua prokrastinasi adalah penundaan,namun tidak semua penundaan adalah prokrastinasi.

Istilah prokrastinasi pertama kali digunakan oleh Brown dan Holzman yang dikutip Ghufron dan Risnawati, yang menjelaskan bahwa prokrastinasi sebagai suatu kecenderungan menunda-nunda penyelesaian suatu tugas atau pekerjaan(Nur Ghufron, 2010).Steel dalam Ferrari mengatakan bahwa prokrastinasi adalah, "to voluntarily delay an intended course of action despiteexpecting to be worse off for the delay"(Ferrari, 2010).Artinya prokrastinasi adalahmenunda dengan sengaja kegiatan yang ingin dilakukan walaupun mengetahui penundaan tersebut dapat menghasilkan dampak yang buruk.Solomon \& Rothblum dalam Ferrari(Ferrari, 2010) menyatakan bahwa, "procrastination as the act of needlessly delaying task to thepoint of experiencing subjective discomfort".Pernyataan

inimenjelaskan bahwa suatu penundaan dikatakan sebagai prokrastinasi apabila dilakukan 
secara berulang-ulang dansengaja serta akan menimbulkan perasaan yang tidak nyaman serta secara subyektif dirasakan oleh pelaku prokrastinasi.Hal yang serupa juga diungkapkan oleh Ferrari, Johnson dan McCown(Josep R. Ferrari, 1995), mereka menyatakan bahwa, "Procrastinastion as thepurposive delay of starting or completing a task to the point of subjective discomfort.'Prokrastinasi diartikan sebagai penundaanyang dilakukan dengan sengaja untuk memulai ataupun penyelesaian tugas sampai subjek merasa tidan nyaman.

Miligram

memberikan

gambaran prokrastinasi ke dalam empat perilaku spesifik yang meliputi: (1) suatu perilaku yang melibatkan unsur penundaan, baik untuk memulai maupun menyelesaikan suatu tugas atau aktivitas; (2) menghasilkan akibatakibat lain yang lebih jauh misalnya keterlambatan menyelesaikan tugas maupun kegagalan dalam mengerjakan tugas; (3) melibatkan suatu tugas yang dipersepsikan oleh prokrastinator sebagai suatu tugas yang penting, seperti misalnya tugas sekolah; dan (4) menghasilkan keadaan emosional yang tidak menyenangkan seperti perasaan cemas, bersalah, marah dan panik (Nur Ghufron, 2010).

Pendapatlain

disampaikanolehSilver,bahwa seorangprokrastinatoratau pelaku prokrastinasitidakbermaksud

untuk menghindari atau tidak mau tahu dengan tugas yangdihadapi, akan tetapi mereka hanya ingin menempatkan tugasnya diwaktu yang optimal untuk menjamin kemungkinan berhasil

menyelesaikannya dengan

maksimal.Sementara Ellis dan

Knaus menyatakan bahwa prokrastinasimerupakan kebiasaan penundaan yang tidak bertujuan dan prosespenghindaran tugas yang sebenarnya tidak perlu dilakukan. Hal initerjadi kerena adanya ketakutan untuk gagal dan pandangan bahwa segala sesuatu harus dilakukan dengan benar.Seseorang yang mempunyai kecenderungan untuk menundaatau

tidaksegeramemulaipekerjaan,ketika menghadapisuatupekerjaan atau tugas disebut sebagai prokrastinator. Burka dan Yuenmenegaskan bahwa, prokrastinator memiliki aspek yang irasional,sebabmereka memilikipandanganbahwa suatu tugasharusdiselesaikan dengan sempurna sehingga ia merasa lebih aman untuk tidak melakukannya dengan segera. la berpendapat bahwa, jika mengerjakan tugas dengan segera akan menghasilkan sesuatu yang tidak maksimal.

Menurut Ferrari, dkk (Josep R. Ferrari, 1995), sebagai suatu perilaku penundaan, seorang prokrastinator cenderung:

Menundaan untuk memulai dan menyelesaikan tugas; (2) Terlambat dalam mengerjakan tugas; Kesenjangan waktu antara rencana dan kinerja aktual, dan (4) Melakukan aktivitas yang menyenangkan.Seseorang yang melakukan prokrastinasi tahu bahwa tugas tersebut harus segera diselesaikan. Akan tetapi, dia menunda-nunda untuk memulai ataupun menyelesaikannya. 
Seorang prokrastinator
menghabiskan waktu yang
dimilikinya untuk mempersiapkan diri
secara berlebihan. Selain itu, juga
melakukan hal-hal yang tidak
dibutuhkan dalam penyelesaian
suatu tugas, ranpa memperhitungkan keterbatasan waktu yang dimilikinya. Kadangkadang tindakan tersebut mengakibatkan seseorang tidak berhasi menyelesaikan tugasnya secara memadai. Kelambanan, dalam arti lambannya kerja seseorang dalam melakukan suatu tugas dapat menjadi ciri utama prokrastinator akademik.

Seorang prokrastinator mempunyai kesulitan untuk melakukan sesuatu sesuai dengan batas waktu yang telah ditentukan sebelumnya. Selain itu, seorang prokrastinator sering mengalami keterlambatan dalammemenuhi deadline yang telah ditentukan, baik oleh orang lain maupun rencana yang telah dia tentukan sendiri. Seseorang mungkin telah merencanakan mulai mengerjakan tugas pada waktu yang telah ia tentukan sendiri. Akan tetapi, ketika saatnya tiba dia tidak juga melakukannya sesuai dengan apa yang telah direncanakan sehingga menyebabkan keterlambatan ataupun kegagalan untuk menyelesaikan tugas secara memadai.

Seorang prokrastinator dengan sengaja tidak segera melakukan tugasnya. Akan tetapi, menggunakan waktu yang dia miliki untuk melakukan aktivitas lain yang dipandang lebih menyenangkan dan mendatangkan hiburan, seperti membaca koran, majalah atau buku cerita lainnya, nonton, ngobrol, jalan, mendengarkan musik sehingga menyita waktu yang dia miliki untuk mengerjakan tugas yang harus diselesaikannya.

Berdasarkan definisi yang diuraikan, dapat disimpulkan bahwa prokrastinasi merupakan suatu tindakan penundaan dalam memulai maupun menyelesaikan tugas yang dilakukan secara sengaja dan berulang dengan melakukan aktivitas lain yang lebih menyenangkan dan tidak ada kaitannya dengan tugas tersebut hingga menimbulkan perasaan yang tidak nyaman bagi pelakunya.

Ferrari (Ferrari, 2010) menyatakan bahwa terdapat tiga jenis prokrastinator, diantaranya yaitu: (1) Arousal Procrastinators: disebut juga Thrill-seeker atau pencarisensasi. Jenis penunda ini mengerjakan atau menangani tugasnya pada menit-menit terakhir sehingga terburu-buru dalam menyelesaikannya; (2) Avoidance Procrastinators: jenis penunda ini selalu menghindaritugas atau merasa bahwa tugas tersebut membosankan. Hal tersebut dilakukan mungkin untuk menghindari perasaan takut gagal (fear of failure) atau bahkan takut sukses (fear of success). Mereka lebih suka jika orang lain berpikir bahwa mereka kurang usaha dibandingkan kurang mampu. Selain itu, mereka juga ingin menghindari sesuatu yang mereka anggap tidak menyenangkan; (3) Decisional Procrastinators: jenis penunda ini selalu ragu dalammengambil keputusan. Mereka tidak dapat 
membuat keputusan atau memberikan kesimpulan dengan tepat waktu. Dengan tidak membuat keputusan, mereka merasa terbebas dari tanggung jawab.

Hal yang serupa juga diungkapkan oleh Srini, ia membagi prokrastinator kedalam tiga jenis, yakni: (1) Arousal Procrastinators: jenis penunda ini sangat sukamengerjakan segala sesuatunya pada menit-menit terakhir. Tekanan yang dialaminya akan membuat mereka bergairah dalam menyelesaikan tugasnya, tetapi disisi lain mereka juga merasaterbebani. Pada dasarnya, mereka merasakan stress yang luar biasa; (2)Avoidant Procrastinators: jenis penunda ini cenderungmelakukan penghindaran terhadap tugas. Penghindaran tersebut dilakukan sebab mereka tidak tahan menghadap atau melakukannya. Mereka biasanya akan merasa lebih baik jika tidak melakukannya. Sebaliknya, jika mereka melakukannya, mereka akan merasa bersalah; (3) Indecisive Procrastinators: atau disebut juga decisional procrastinators. Jenis penunda ini tidak tahu langkah yang harusmereka ambil atau tindakan yang harus mereka ambil. Dengantidak membuat keputusan, mereka berpikir tidak perlu bertindak (Bob Proctor, 2014).

Sedangkan Snyder hanya mengemukakan dua jenis prokrastinator namun tidak jauh berbeda dengan sebelumnya, diantaranya yaitu: (1) Arousal Procrastinators: jenis penunda ini memulai ataumenyelesaikan tugasnya pada tengat waktu (deadline). mereka merasa bergairah jika mengerjakannya di akhir waktu dan memiliki nilai yang menguntungkan. Namun tampaknya, mereka yang mengerjakan tugas pada menit-menit terakhir justru dapat menghasilkan kinerja yang buruk karena dibawah tekanan; (2) Avoidance Procrastinators: jenis penunda ini selalu menghindaritugas yang menurutnya tidak menyenangkan atau tidak disukai. Mereka merupakan orang-orang yang takut gagal atau sukses. Mereka lebih suka dilihat atau dinilai sebab kurang usaha dibandingkan kurang mampu (Lawrence C.R. Snyder, Tt).

Selanjutnya, Miller (Miller, 2011)menyatakan bahwa terdapat tujuh jenis prokrastinator, yakni: (1) Chronic Procrastinators: atau penunda kronis. Jenis inimenganggap bahwa menundanunda merupakan gaya hidup mereka; (2) Optimistics Procrastinators: jenis penunda ini percaya bahwamereka merasa akan menghasilkan yang terbaik jika bekerja di bawah tekanan; (3) Thrillseeking Procrastinators: atau pencari sensasi. Jenispenunda ini menyibukkan dirinya dengan melakukan dan menyelesaikan tugasnya pada tengat waktu (deadline); (4) Distraction Procrastinators: mereka membiarkan segala sesuatudan apapun (menunda-nunda tugas) untuk mengubah hari mereka; (5) Rebellious Procrastinators: jenis penunda ini benar-benar tidakingin melakukan apapun dan akan melakukan penundaan terhadap tugas-tugasnya;

(6) Avoiding 
Procrastinators: jenis penunda ini merasa takutterhadap hasil yang negatid atau tidak sesuai dengan yang diharapkannya, sehingga melakukan penundaan terhadap tugas menjadi pilihan mereka; (7) Indecisive Procrastinators: jenis penunda ini tidak dapatmemikirkan atau mengambil langkah mereka dan lebih memilih untuk tidak melakukan atau menyelesaikannya.

Berdasarkan uraian jenisjenis prokrastinator tersebut, secara umum dapat disimpulkan bahwa terdapat tiga jenis prokrastinator, yakni:arousal procrastinators atauthrill-seeking Procrastinators, yang ditandai (1) Mengerjakan tugas-tugasnya pada menit-menit terakhir; (2) Merasa lebih bergairah jika mengerjakan tugasnya dibawah tekanan, dan (3) Mengalami stress yang luar biasa. Jenis avoidance Procrastinatorsyang memiliki ciri: (1)Selalu menghindari tugas yang menurutnya membosankan dan tidak menyenangkan atau tidak disukai; (2) Merasa takut gagal (fear of failure) atau takut terhadap hasil yang tidak sesuai dengan yang diharapkan, dan (3) Lebih suka dinilai sebab kurang usaha daripada dianggap kurang mampu.

Prokrastinasi dapat terjadi pada siapa saja, termasuk ibu rumahtangga, para pegawai kantor, kalangan akademisi termasuk

siswa,mahasiswa, ataupunpendidik.

Padasiswa,prokrastinasibiasanyadila kukan pada tugas-tugas yang berhubungan dengan akademiknya.Istilahpenundaantugas dalambidangakademikdisebutdenga nprokrastinasi akademik. Rothblum,SolomondanMu rakmi,menjelaskan

bahwaprokrastinasi akademik merupakan kecenderungan untuk (a) selaluatau hampir selalu menunda tugas akademik dan (b) selalu atauhampir selalu merasakan kegeliasahan terhadap prokrastinasi tersebut(Allcott, 2015).

Selanjutnya,Solomon

danRothblummembagi

prokrastinasiakademik dalam enam area, diantaranya: (1) Tugas mengarang: meliputi penundaan melaksanakan kewajiban atau tugas-tugas menulis, misalnya menulis makalah, laporan atau tugas mengarang lainnya; (2) Belajar untuk ujian: mencakup penundaan belajar untuk menghadapi ujian, misalnya ujian tengah semester, akhir semester atau ulangan mingguan, dan (3) Membaca: meliputi adanya penundaan untuk membaca buku atau referensi yang berkaitan dengan tugas akademik yang diwajibkan; (4) Melakukan tugas administratif: seperti menyalin catatan, mendaftarkan diri dalam presensi kehadiram, dafatar peserta pratikum, dan sebagainya; Menghadiri pertemuan: yaitu penundaan maupun keterlambatan dalam menghadiri pelajaran, praktikum dan pertemuanpertemuan lainnya, dan (6) Kinerja akademik secara keseluruhan: penundaan dalam kinerja akademik secara keseluruhan.

Sejalan dengan hal tersebut, Ellis dan Knausdalam Myron(Myron $\mathrm{H}$. Dembo, 2008)mendefinisikanprokrastinasi akademik sebagai kecendurungan untuk

menunda 
tugasakademikyangmeliputipenunda andalammemulai ataupunmenyelesaikan tugas makalah, essai, belajar untuk ujian, mendaftarkelas, membuat janji dengan instruktur dan menyelesaikan tugas tepat waktu. OnwuegbuziedanCollinsmenyatakan bahwaprokrastinasiakademik merupakan tindakan untuk menunda tugas-tugas akademik.Penundaan tersebut kebanyakan dilakukan oleh para pelaku/pelajar dalam tugas menulis karangan. Berdasarkan uraian definisi diatas, dapat disimpulkan bahwaprokrastinasi akademik merupakan kecenderungan para pelajar untukmenunda memulai maupun menyelesaikan tugas-tugas akademiknyasecara sengaja dan dilakukan berulang-ulanghingga mereka merasagelisah dan tidak nyaman. Tugas-tugas akademik tersebut umumnyamencangkup tugas mengarang, belajar untuk ujian dan hadir dalampertemuan kelas.

\section{Lokus Kendali (Locus of control)}

Kesuksesan dan kegagalan yang terjadi dalam kehidupanindividu tersebut berkaitan dengan keyakinan diri pada individu atas kendalidiri yang dilakukan. Keyakinan yang dimiliki individu terhadap segalasesuatu yang terjadi pada dirinya dikenal dengan locus of control.Locus of control merupakan konsep dari teori sosial learning yangtelah dikembangkan oleh Julian Rotter. "Rotter's notion of locus of controlrefers to the extent to which people tends to view events as under theirpersonal control

\section{versuscontrol of externalforces(T. Stuart Watson, 244).}

Randy J. Larsen (Buss., 2005)mendefinisikan locus of control sebagaia concept that describe a person's persception ofresponsibility for the events in his or her life. More specifically, locusof control refers to whether people tend to locate that responsibility internally, within themselves, or externally, in fate, luck, or chance. Selanjutnya McShane dan Glinow(Glinow, 2010)sampai pada kesimpulan bahwa locus of control is defined as aperson's general belief about the amount of control he or she has over personal life events. Lokus kendali ini menurut Robbins dan Coulter (Stephen Robbins, 2009)bisamengendalikan nasib seseorang. Artinya, orang lain melihat diri mereka sendirisebagai pion nasib. Mereka juga berpendapat bahwa apa yang terjadi dalamkehidupan mereka itu disebabkan oleh keberuntungan atau kesempatan. Berdasarkan beberapa pendapat sebagaimana telah diuraikan, dapat ditarik kesimpulan bahwa locus ofcontrolatau lokus kendalimerupakan keyakinan dalam diri seseorang atas konrol diri terhadapperistiwa yang terjadi dalam hidupnya apakah dipengaruhi oleh kendali dirisendiri atau kendali dari luar seperti nasib, keberuntungan, orang lain ataukesempatan.Berdasarkan teori Rotter, locus of control dibedakan menjadi duayaitu internal locus of controldan eksternallocusofcontrol.Menur 
ut Rotterdalam David Heper(Heper, 2003)individuals believe that the outcomes of events are either within or beyond their personal control. An individual with a belief in internal control perceives that an event is 'contigent upon his own behavior or his own relatively permanent characteristics. Internal people thus believe that they have some control over events in their life and that they are, therefore, responsible for their own destiny. They expect that the environment can be manipulated by their own actions. External people interpret events as the result of outside factors which they cannot influence, such as luck, chance and fate, or they see events as under the control of powerful others or as unpredictable because of the great complexity of the forces surrounding them.

Menurut Santrock (John W., 2005)orang yang memiliki kontrol internal menganggap bahwaperilaku dan tindakan mereka sendiri bertanggung jawab atas konsekuensiyang terjadi pada mereka. Orang dengan kendali eksternal percaya bahwa,terlepas dari bagaimana mereka berperilaku, mereka tunduk pada keinginannasib, keberuntungan, atau orang lain.McShane dan Glinow(Glinow, 2010)menyimpulkan bahwa Individuals with more of an internal locus of control believe thattheir personal characteristics mainly influence life's outcomes. Those with more of an external locus of control believe that events in their life are due mainly to fate, luck, or conditions in the external environment. Locus of control is a generalized beliefe, so people withan external locus can feel in control in familiar situations (sucha as performing common task).

Ivancevich (Ivancevich, 2007)menggolongkan locus of control menjadi dua, yaituinternal dan eksternal.Beberapa orang yakin bahwa mereka mengatur dirinya sendiri secara sepenuhnya bahwa mereka merupakan penentu dari nasib mereka sendiri dan memiliki tanggung jawab pribadi untuk apa yang terjadi terhadap diri mereka. Mereka digolongkan sebagai internal. Yang lainnya memandang diri mereka secara tak berdaya diatur oleh nasib, dikendalikan oleh kekuatan dari luar dimana, kalaupun ada, mereka hanya memiliki sangat sedikit pengaruh. Ketika mereka berkinerja dengan baik, mereka yakin bahwa hal tersebut disebabkan oleh keberuntungan atau karena tugas tersebut merupakan tugas yang mudah. Mereka digolongkan sebagai eksternal.Berdasarkan teori di atas dapat ditarik kesimpulan bahwa locus ofcontrol dibedakan menjadi internal dan eksternal yang dijadikan sebagaiindikator. Orang yang memiliki internal locus of control yakin bahwaperistiwa yang terjadi dalam hidupnya sepenuhnya dipengaruhi oleh dirinyasendiri. Orang yang memiliki eksternal locus of control yakin bahwa peristiwa yang terjadi dalam hidupnya dipengaruhi oleh faktor dari luar seperti nasib, keberuntungan, atau orang lain.

\section{METODOLOGI PENELITIAN}


Metode yang digunakan dalam penelitian ini adalah metode kuantitatif kategori survey dengan jenis pendekatan korelasional. Metode penelitian survey digunakan untuk mendapatkan data dari suatu tempat tertentu yang alamiah, dengan melakukan perlakuan tertentu dalam pengumpulan datanya, misalnya seperti mengedarkan kuesioner, tes, dan wawancara terstrukur. Metode ini dipilih karena sesuai dengan tujuan penelitian yaitu memperoleh data dengan cara kuesioner untuk mengetahui apakah terdapat hubungan antara locus of control dengan prokrastinasi. Populasi dalam penelitian ini adalah mahasiswa Pendidikan Ekonomi angkatan 2013. Sampel dalam penelitian ini adalah mahasiswa Pendidikan Akuntansi, Pendidikan Administrasi Perkantoran dan Pendidikan Ekonomi Koperasi yang berjumlah 127 orang.Teknik analisis yang digunakan dalam penelitian ini adalah korelasi.

\section{HASIL DAN PEMBAHASAN}

Deskripsi data hasil penelitian dimaksudkan untuk memberikan gambaran umum mengenai hasil pengolahan data yang didapat dari dua variabel dalam penelitian ini, yaitu variabel bebas dan variabel terikat. Variabel bebas dari penelitian ini adalah Locus of Control (X) dan variabel terikat dari penelitian ini adalah Prokrastinasi (Y). Untuk mendeskripsikan dan menguji pengaruh variabel bebas dan variabel terikat dalam penelitian ini, maka pada bagian ini akan disajikan deskripsi data dari masing- masing variabel berdasarkan data yang diperoleh di lapangan. Skor yang akan disajikan adalah skor yang diolah dari data mentah dengan menggunakan statistik deskriptif yaitu skor rata-rata dan simpangan baku atau standar deviasi dari masing-masing variabel.

Berdasarkan data yang terkumpul, diperoleh skor terendah 43 dan skor tertinggi adalah 100, jumlah skor adalah 8944 sehingga rata-rata skor prokrastinasi adalah 70,43 , Varians $\left(S^{2}\right)$ sebesar 93,93 dan standar deviasisebesar 9,69. Distribusi data variabel prokrastinasi menyebar antara 43-100, dimana banyak kelas adalah 8 dengan panjang interval 7. Data Locus of Control diperoleh melalui instrumen penelitian yang berupa kuesioner model skala likert dengan jumlah item yang digunakan sebanyak 30 pernyataan dengan jumlah yang tidak valid sebanyak 5 pertanyaan sehingga yang digunakan pada uji final berjumlah 25 butir pertanyaan. Kuesioner ini diisi oleh 127 mahasiswa Pendidikan Ekonomi angkatan 2013 Fakultas Ekonomi UNJ. Berdasarkan data yang terkumpul diperoleh skor terendah 63 dan skor tertinggi adalah 117, jumlah skor 11940, sehingga ratarata skor locusof control adalah 94,02 , Varians $\left(S^{2}\right)$ sebesar 153,67 dan standar deviasi12,40. Distribusi data variable locus of control menyebar antara 63-117, dengan banyak kelas adalah 7 dengan panjang interval 8. Dibawah ini dapat dilihat distribusi frekuensi data dari variable locus of control.

Berdasarkan data yang diperoleh, dapat diketahui bahwa 
mahasiswa Pendidikan Ekonomi angkatan 2013, Fakultas Ekonomi UNJ memiliki locusof control yang baik. Hal ini ditunjukkan dengan 109 mahasiswa dari 127 mahasiswa yang dijadikan sampel memiliki locus of control diatas rata-rata. Hal ini berbanding terbalik dengan tindakan penundaan tugas yang dilakukan oleh mahasiswa (prokrastinasi), dengan skor rata-rata 74,43 , terdapat 113 mahasiswa dengan skor diatas rata-rata. Hal ini menunjukkan bahwa dari 127 mahasiswa yang dijadikan sampel, terdapat 113 mahasiswa yang cenderung melakukan tindakan prokrastinasi atau penundaan terhadap tugas-tugasnya.

Berdasarkan hasil penelitian, diperoleh bahwa nilai kooefisien dari model persamaan regresi dapat diartikan bahwa setiap kenaikan satu variabel $X$ (locus of control) akan menurunkan variabel $Y$ (Prokrastinasi). Data yang digunakan dalam model regresi adalah berdistribusi normal, berbentuk linier dan berarti.

Bentuk hubungan antara variabel locus of control dengan prokrastinasi mahasiswa Pendidikan Ekonomi angkatan 2013 Fakultas Ekonomi yang terdiri dari kelas Pendidikan Akuntansi A, Pendidikan Akuntansi B, Pendidikan Administrasi Perkantoran A, Pendidikan Administrasi Perkantoran B, Pendidikan Ekonomi Koperasi A dan Pendidikan Ekonomi Koperasi B memiliki persamaan regresi $\hat{Y}=$ 139,57 - 0,74X. Persamaan regresi tersebut dapat dimaknai bahwa setiap kenaikan satuskor pada locus of control (X) akan mengakibatkan penurunan prokrastinasi $(Y)$ sebesar $-0,74$ pada konstanta 139,57 .

Berdasarkan hasil penelitian, data yang diperoleh menunjukkan bahwa data tersebut berdistribusi normal. Hal ini dapat dilihat dari $L_{\text {hitung }}<L_{\text {tabel }}(0,0764<0,0786)$. Ini berarti bahwa data berdistribusi normal dan penelitian dapat dilanjutkan pada pengujian Hipotesis.Berdasarkan perhitungan uji linieritas regresi yang bertujuan untuk mengetahui apakah dua variabel mempunyai pengaruh yang linier atau tidak secara signifikan, dapat diketahui bahwa Hasil penghitungan menunjukkan ( $\left.F_{\text {hitung }}\right)$ $0,19<\left(F_{\text {tabel }}\right) 1,59$, ini berarti $\mathrm{Ho}$ diterima dan model regresi linier.

Selanjutnya, uji keberartian regresi Uji keberartian regresi digunakan untuk mengetahui apakah persamaan regresi yang diperoleh berarti atau tidak berarti, Berdasarkan hasil perhitungan $\mathrm{F}_{\text {hitung }}$ sebesar 86,89 dan untuk $F_{\text {tabel }}$ adalah 3,939 , sehingga ( $\left.F_{\text {hitung }}\right)$ $86,89>\left(F_{\text {tabel }}\right) 3,939$ dan dapat disimpulkan bahwa model persamaan regresi adalah berarti. Hubungan antara locus of control dengan prokrastinasi memiliki nilai korelasi -0,6403, maka keeratan hubungan antara locus of control dengan prokrastinasi adalah negatif dan tergolong kuat. Artinya, jika locus of control meningkat maka prokrastinasi akan menurun.

Berdasarkan pengujian signifikansi korelasi antara pasangan data locus of control dengan prokrastinasi, diperoleh thitung yang lebih kecil darit tabel $(-9,321<1,979)$, maka dapat disimpulkan bahwa terdapat pengaruh yang signifikan 
antara locus of control dengan prokrastinasi.

Dalam penelitian yang dilakukan pada mahasiswa Pendidikan Ekonomi angkatan 2013 Fakultas Ekonomi UNJ, diketahui bahwa mahasiswa memiliki tingkat locus of control yang baik. Hal ini ditunjukkan dengan sebanyak 81 dari 127 mahasiswa yang memiliki tingkat locus of control diatas ratarata. Hal ini berarti bahwa rata-rata mahasiswa Pendidikan Ekonomi angkatan 2013 Fakultas Ekonomi UNJ dapat mengatur belajarnya dengan baik, sehingga mereka cenderung menepati tugas-tugasnya atau menghindari tindakan penundaan (prokrastinasi rendah).

Sebaliknya, jika mahasiswa tidak dapat mengatur dirinya dalam belajar dengan baik, akan cenderung melakukan penundaan terhadap tugas-tugasnya. Hal ini sesuai dengan pernyataan yang disampaikan oleh Wolters yang menyatakan bahwa, pelajar yang tidak dapat mengatur dirinya dalam belajar lebih mungkin untuk melakukan penundaan ketika diberi tugas belajar.

Seorang mahasiswa yang memiliki locus of control yang baik cenderung tidak akan melakukan tindakan prokrastinasi. Hal ini dikarenakan mahasiswa yang memiliki locus of control baik menggambarkan seorang mahasiswa yang mampu secara mandiri melakukan pengaturan terhadap hal-hal yang mengarahkan pikiran, motivasi dan perilaku ke arah pencapaian tujuan. Besarnya pengaruh variabel locus of control dengan prokrastinasi mahasiswa dapat diketahui dengan melihat hasil penghitungan uji koefisien determinasi yang diperoleh sebesar $41,01 \%$. Hal ini berarti bahwa, tingkatprokrastinasi mahasiswa Pendidikan Ekonomi angkatan 2013 Fakultas Ekonomi UNJ dipengaruhi oleh locus of control sebesar $41,01 \%$.

Hasil penelitian ini juga sesuai dengan penelitian yang dilakukan oleh Agung Wahyu Handaru dan Evi Permatasari (2014) yang berjudul Analisis perbedaan tingkat prokrastinasi ditinjau dari gender, socio-personal, locus of control, serta kecemasan emosional, studi pada mahasiswa Manajemen FEUNJ dalam penelitiannya juga mengemukakan bahwa locus ofcontrol memiliki hubungan negatif dan signifikan dengan prokrastinasi.

Sedangkan locus of control berpengaruh negatif signifikan terhadap prokrastinasi akademik mahasiswa yang mengambil mata kuliah Skripsi pada Fakultas Psikologi Universitas Airlangga, oleh Rayu Nilakantie dan Endah Mastuti. Karena locus of control tidak berlaku di segala situasi, namun lebih ditentukan oleh kemampuan personal. Hasil penelitian berikutnya juga menunjukkan hasil negatif yaitu hubungan antara locus ofcontrol dengan prokrastinasi yang pernah diteliti oleh Farrokhlagha Heidaridan Farnaz Imanpoor(Imanpoor, 2014)dalam penelitiannya mengemukakan bahwa locus of control berpengaruh negatif dan signifikan terhadap prokrastinasiakademik siswa Sekolah Menengah Atas.Hal tersebut berarti bahwa, individu 
dengan kemampuan locus ofcontrol yang rendah termasuk dalam tingkat prokrastinasi yang lebih besardibandingkan dengan individuindividu yang memiliki kemampuan locus ofcontrol yang baik.

Berdasarkan hasil penelitian ini, dapat diketahui bahwa semakin tinggi locus of control mahasiswa maka ia akan cenderung menghindari tindakan prokrastinasi (penundaan) terhadap tugas-tugas akademiknya. Demikian pula sebaliknya, semakin rendah tingkat locus of control mahasiswa maka cenderung suka menunda-nunda tugasnya (melakukan tindakan prokrastinasi). Namun perlu diingat bahwa locus of control bukanlah faktor satu-satunya yang mempengaruhi prokrastinasi. Masih ada faktor lain seperti gaya pengasuhan orang tua, motivasi belajar, motivasi berprestasi, dan faktor fisik seperti kelelahan serta kondisi lingkungan yang kondusif.

Dalam penelitian ini, peneliti menyadari adanya keterbatasanketerbatasan yang menyebabkan tingkat keakuratan penelitian ini, tidak sepenuhnya mutlak. Adanya keterbatasan-keterbatasan yang peneliti alami dalam meneliti hubungan antara locus of control dengan prokrastinasi pada mahasiswa seperti populasi terjangkau pada penelitian ini hanya terbatas pada mahasiswa Pendidikan Ekonomi yang terdiri dari konsentrasi Pendidikan Akuntansi, Pendidikan Administrasi Perkantoran dan Pendidikan Ekonomi Koperasi, Fakultas Ekonomi UNJ saja, sehingga hasil yang diperoleh dalam penelitian ini tidak dapat digeneralisasikan pada mahasiswa lain selain mahasiswa Pendidikan Ekonomi angkatan 2013 Fakultas Ekonomi UNJ.

Kemudian dalam penelitian ini variabel yang diteliti terbatas. Penelitian ini hanya melibatkan satu variabel $X$ saja yaitu locus of control yang berakibat pada variabel $Y$ yaitu prokrastinasi.

Sedangkan prokrastinasi dapat dipengaruhi oleh beberapa hal seperti gaya pengasuhan orang tua,motivasi belajar, motivasi berprestasi, dan faktor fisik seperti kelelahan serta kondisi lingkungan yang kondusif.

Secara metodologis penelitian ini telah mengikuti prosedur ilmiah yang berlaku. Namun peneliti menyadari tentu masih ada kelemahan-kelemahan yang terdapat di dalamnya. Bisa jadi dalam hal jumlah sampel dan teknik pengambilan sampelnya, instrumennya atau hal-hal lain yang luput dari kontrol atau ketelitian peneliti dan keterbatasan kemampuan yang dimiliki peneliti untuk meneliti lebih dalam.

\section{KESIMPULAN DAN SARAN}

Berdasarkan pengolahan data statistik, deskripsi, analisis, dan interpretasi data yang telah dilakukan dan diuraikan pada babbab sebelumnya, maka dapat disimpulkan bahwa: (1) Terdapat pengaruh yang negatif antara locus of control dengan prokrastinasi pada mahasiswa Pendidikan Ekonomi Fakultas Ekonomi Universitas Negeri Jakarta. Dengan demikian, dapat disimpulkan dalam penelitian ini bahwa semakin tinggi locus of control mahasiswa maka akan 
semakin rendah tingkat prokrastinasi pada mahasiswa. Begitu pun sebaliknya, semakin rendah locus of control mahasiswa maka akan semakin tinggi prokrastinasi yang dilakukan oleh mahasiswa tersebut; (2) Berdasarkan hasil penelitian yang telah dilakukan dapat diketahui bahwa prokrastinasi pada mahasiswa Pendidikan Ekonomi angkatan 2013 dipengaruhi oleh locus of control sebesar $35,72 \%$,sedangkan sisanya sebesar $64,28 \%$ dipengaruhi oleh faktor lain, dan (3)

Indikator yang berpengaruh dalam variabel locus of control adalah tahap evaluasi. Sub indikator yang berpengaruh dalam tahap evaluasi adalah memberikan umpan balik atau saran terhadap proses dan hasil belajar. Kemudian untuk varibel prokrastinasi, indikator yang paling berpengaruh adalah arousal procrastinator. Sub indikator yang berpengaruh dalamarousal procrastinator yaitu merasa lebih bergairah jika mengerjakantugas di bawah tekanan.

Berdasarkan kesimpulan yang telah dikemukakan, bahwa terdapat pengaruh yang negatif antara locus of control terhadap mahasiswa Pendidikan Ekonomi Fakultas Ekonomi UNJ. Dengan demikian implikasi yang diperoleh berdasarkan penelitian ini adalah tahap evaluasi merupakan indikator tertinggi dalam locus of control dan tahap perencanaan menjadi indikator terendah dalam locus of control pada mahasiswa Pendidikan Ekonomi Fakultas Ekonomi UNJ. Hal ini terjadi karena perencanaan yang dilakukan mahasiswa belum maksimal. Rata-rata dari mahasiswa masih belum bisa menentukan strategi belajar yang tepat untuk digunakan dalam memahami materi perkuliahan. Dalam tahap evaluasi, sub indikator yang paling berpengaruh yaitu memberikan saran dan umpan balik atas proses dan hasil belajar. Banyak mahasiswa yang peduli terhadap proses dan hasil belajarnya, mereka cenderung untuk berusaha melakukan perbaikan jika proses dan hasil belajarnya belum maksimal. Selanjutnya, sub indiktor terendah dalam tahap perencanaan yakni merencanakan strategi belajar. Hal ini terjadi karena rata-rata mahasiswa Pendidikan Ekonomi Fakultas Ekonomi UNJ belum bisa menggunakan strategi belajar yang tepat untuk memahami materi perkuliahan. Oleh sebab itu, mahasiswa harus diarahkan untuk menggunakan strategi dalam belajarnya agar lebih mudah dalam memahami perkuliahankhususnya pada mata kuliah yang tingkat kesulitannya tinggi, sehingga hasil belajar yang didapatkan lebih memuaskan.

Selanjutnya, implikasi yang diperoleh berdasarkan penelitian, arousalprocrastinator mahasiswa Pendidikan Ekonomi Fakultas Ekonomi UNJ lebintinggi dibandingkan dengan dua indikator lainnya. Sub indikator yang berpengaruh dalam arousal procrastinator yaitu merasa lebih bergairah jika mengerjakan tugas di bawah tekanan. Hal ini dikarenakan mahasiswa Pendidikan Ekonomi angkatan 2013 lebih bersemangat jika mengerjakan tugas jika sudah 
mendekati deadline, mereka lebih berkonsentrasi dan meras tertantang jika mengerjakan tugas-tugasnya ketika sudah mendekati waktu pengumpulan tugas. Sedangkan indikator yang paling rendah yaitu avoidanceprocrastinators dan sub indikator terendahnya yaitu menghindari tugas yangtidak menyenangkan atau tidak disukai. Hal ini terjadi dikarenakan mahasiswa merasa materi perkuliahan tersebut tidak menyenangkan dan tidak suka terhadap pelajar tersebut, mereka tetap mengerjakan dan menyelesaikan tugas-tugas tersebut sebagai bentuk tanggung jawab yang harus mereka laksanakan dan penuhi guna mendapatkan penilaian. Locus of control merupakan faktor yang mempengaruhi prokrastinasi.Tingkat prokrastinasi mahasiswa Pendidikan Ekonomi angkatan 2013 dipengaruhi oleh locus of controlsebesar $35,72 \%$, sisanya sebesar $64,28 \%$ dipengaruhi oleh faktor lain seperti gaya pengasuhan orang tua, motivasi belajar, motivasi berprestasi, kondisi fisik seperti kelelahan dan kondisi lingkungan yang kondusif.

Penelitian ini memberikan informasi bahwa locus of control memiliki hubungan dengan prokrastinasi pada mahasiswa. Namun masih banyak faktor lain yang mempengaruhi prokrastinasi seperti gaya pengasuhan orang tua, motivasi belajar, motivasi berprestasi, kondisi fisik seperti kelelahan dan kondisi lingkungan yang kondusif. Oleh karena itu, diharapkan dalam penelitian selanjutnya untuk mengetahui faktor- faktor yang mempengaruhi prokrastinasi selain yang diteliti dalam penelitian ini agar diperoleh gambaran yang lebih menyeluruh.

Bagi dosen, diharapkan berupaya untuk mengedukasi mahasiswa mengenai locus of control agar mahasiswa dapat mengatur kegiatan belajarnya dengan baik dan terhindar dari tindakan prokrastinasi (penundaan) terhadap tugas-tugasnya. Guru dapat menanamkan locus ofcontrol dengan memberikan contoh-contoh kehidupan nyata pada orang-orang sukses yang kebanyakan diantara mereka dapat mengatur belajarnya dengan baik dan tidak pernah melakukan penundaan terhadap kegiatan yang berkaitan dengan belajarnya, sehingga waktu yang dimilikinya tidak terbuang sia-sia dan mereka dapat mencapai segala sesuatu yang telah mereka rencanakan dengan hasil yang memuaskan.

Bagi mahasiswa, mahasiswa yang memiliki locus of control yang rendah sebaiknya belajar untuk menyusun dan mengatur kegiatan belajarnya agar lebih terarah dan menyenangkan sehingga tujuan belajar dapat tercapai dengan baik. Siswa dapat meningkatkan locus of control dengancara menyusun jadwal belajar, memilih strategi belajar yang tepat, mengawasi setiap pelaksanaan belajar apakah sudah sesuai yang direncanakan atau belum dan melakukan evaluasi terhadap proses belajar yang telah dilakukan dan melakukan koreksi atas hasil belajar yang didapatkan agar lebih ditingkatkan kembali. Jika mahasiswa dapat mengatur bela- 
jarnya dengan baik, akan lebih memprioritaskan segala sesuatu yang telah disusun dan direncanakan untuk belajarnya, sehingga meminimalisir tindakan penundaan (prokrastinasi) yang akan merugikan dirinya, dan pada akhirnya mereka bisa mencapai hasil belajar yang maksimal dan memuaskan.

Bagi orang tua, harus
ditingkatkan dukungannya dalam menumbuhkan locus of control anak-anak mereka. Hal ini dapat dilakukan dengan cara memberikan nasihat-nasihat yang membangun dan cara didik yang disiplin dan tegas, agar anak terpacu untuk mengatur belajarnya dengan baik dan lebih termotivasi dalam belajar, sehingga akan meminimalisir terjadinya tindakan penundaan (prokrastinasi) terhadap tugas-tugas akademiknya.

\section{DAFTAR PUSTAKA}

Agung Wahyu Handaru, E. P. (2014). Analisis Perbedaan Tingkat Prokrastinasi ditinjau dari Gender, Socio-personal, Locus of Control, serta Kecerdasan Emosional: Studi pada Mahasiswa Program Studi Manajemen FE UNJ. Jakarta: Fakultas Ekonomi.

Allcott, G. (2015). How to be a Knowledge Ninja: Study Smarter, Focus Batter, Achieve More. London: Icon Books, Ltd.

Bob Proctor, G. S. (2014). Thoughts are Things: Turning Your Ideas into Realities. USA: Penguin Group.
Buss., R. J. (2005). Personality Psychology (second edition ed.). New York: McGraw Hill.

Ferrari, J. R. (2010). Still Procrastinating? The NoRegrets Guid to Getting It Done. Canada: John Wiley \& Sons, Inc.

Glinow, M. d. (2010). Organizational Behavior. New York: The MacGraw Hill Companies.

Heper, D. (2003). Entrepreneurship and The Market Process. New York: Routledge.

Imanpoor, F. H. (2014). The Relationship between Spiritual Intelligence, Locus of Control, and Academic Procrastination among Iranian High School EFL Learners. Journal of Social Issues and Humanities.

Ivancevich, J. M. (2007). Perilaku dan Manajemen Organisasi Jilid I. Jakarta: Erlangga.

John W., S. (2005). PSYCHOLOGY: ESSENTIALS (Second Edition ed.). New York: McGraw-Hill Companies, INC.

Josep R. Ferrari, J. L. (1995). Procrastination and Task Aoidance. New York: Plenum Press.

Miller, M. (2011). Faithpreneur. USA: Five Star Tax \& Business Solution.

Myron H. Dembo, H. S. (2008). Motivation and Learning Strategies for College Success: A Self-Management Approach. New York: Routledge. 
Nur Ghufron, R. R. (2010). Teoriteori Psikologi. Yogyakarta: Ar-ruzz Media.

Stephen Robbins, M. C. (2009). Management (10th Edition ed.). USA: Pearson Education Inc.

Tefula, M. (2014). Student Procrastination: Seize The day and Get More Work Done. New York: Macmillan Publisher Limited. 